\title{
Review
}
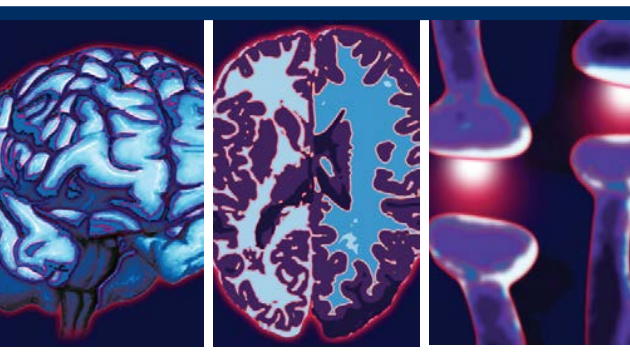

\section{Impact of the Project P.A.T.H.S. in Hong Kong and China}

\author{
Daniel T.L. Shek†
}

\begin{abstract}
This article reviews the impact of a youth enhancement program entitled "P.A.T.H.S. to Adulthood: A Jockey Club Youth Enhancement Scheme" (Project P.A.T.H.S.) initiated and funded by The Hong Kong Jockey Club Charities Trust. The Research Team developed curricula-based programs for Grade 7 to Grade 9 students based on the positive youth development approach and trained over 7,000 teachers and allied professionals. To date, more than 320 schools and 284,400 students (with 601,198 man-times) participated in the project in the Initial, Extension and Community-Based Implementation Phases. Findings based on different evaluation methods showed that the program was well-received by different stakeholders and the participants changed positively after joining the program. Because of its overwhelming success, the project was transplanted to 30+ schools in mainland China with the support of Tin Ka Ping Foundation. Client satisfaction and qualitative evaluation findings suggest that the project has positive impact on holistic development in students in mainland China.
\end{abstract}

\section{Keywords}

Positive youth development, Risk behavior, evaluation, Project P.A.T.H.S

\section{Introduction}

Emergence of youth problems in the global context demands for solutions to prevent adolescent risk behaviour. One strategy is to strengthen adolescent psychosocial competencies via the positive youth development approach (PYD) which would decrease adolescent risk behaviour. In Hong Kong, with a grant of $\mathrm{HK} \$ 400$ million, a project entitled "P.A.T.H.S. to Adulthood: A Jockey Club Youth Enhancement Scheme" (Project P.A.T.H.S.) was initiated by the Hong Kong Jockey Club Charities Trust to develop an age-appropriate, multi-year and evidence-based positive youth development program in 2004. Academics from five universities worked together to develop the program, train potential program implementers, provide support during the implementation, and evaluate the program [1-3].
Initial Implementation Phase (2005-2009)

Conceptually, programs of the Project P.A.T.H.S. were grounded in 15 positive youth development constructs (such as resilience, cognitive competence, self-efficacy and spirituality) present in the effective PYD programs in the field [4]. To systematically evaluate the program and triangulate the findings, different evaluation strategies were adopted (Table 1). Generally speaking, students and workers had positive experiences with the program. Compared with control students, students in the experimental schools also showed more positive (and less negative) developmental trajectories [1,5-9].

\section{Extension Phase (2009-2012) and Community-Based Phase (2013-2015)}

Because of the positive evaluation findings, with a further injection of HK\$350 million,

FHKPS, SBS, JP, Chair Professor, Department of Applied Social Sciences, the Hong Kong Polytechnic University

Associate Vice President (Undergraduate Programme), The Hong Kong Polyechnic University, Li and Fung, Professor in Service leadership Education, Advisory Professor, School of Social Development, East China Normal University, Honorary Professor, Kiang Wu Nursing College of Macau, Adjunct Professor, University of Kentucky College of Medicine

${ }^{\dagger}$ Author for correspondences: Daniel T.L. Shek, Department of Applied Social Sciences, The Hong Kong Polytechnic University Hunghom, P.R.C. Hong Kong

Tel: 852-2766-5652; email: daniel.shek@polyu.edu.hk 


\begin{tabular}{|c|c|c|}
\hline Evaluation Method & Sample & Major Conclusions \\
\hline $\begin{array}{l}\text { 1. Pre-experimental design with } \\
\text { pretest and posttest data }\end{array}$ & $\begin{array}{l}\text { - } 546 \text { students at Wave } 1 \text { with pretest and } \\
\text { posttest data }\end{array}$ & $\begin{array}{l}\text { - Participants showed positive change in different outcome } \\
\text { measures }\end{array}$ \\
\hline $\begin{array}{l}\text { 2. Longitudinal experimental } \\
\text { design (randomized group trial) }\end{array}$ & $\begin{array}{l}\text { - } 24 \text { pairs of schools ( } 1 \text { experimental } \\
\text { school and } 1 \text { control school in each pair) } \\
\text { - At Wave } 8,2,850 \text { experimental subjects } \\
\text { and } 3,640 \text { control subjects }\end{array}$ & $\begin{array}{l}\text { Relative to control subjects, experimental subjects showed } \\
\text { faster growth rates and slower decline rates in PYD } \\
\text { measures } \\
\text { Relative to control subjects, experimental subjects showed } \\
\text { slower growth rates and faster decline rates in risk behavior } \\
\text { measures }\end{array}$ \\
\hline $\begin{array}{l}\text { 3. Evaluation based on subjective } \\
\text { evaluation (students) }\end{array}$ & - 206,313 students & $\begin{array}{l}\text { - Positive evaluation of program, workers and usefulness } \\
\text { revealed by quantitative and qualitative findings } \\
\text { - Convergence of subjective outcome and objective outcome } \\
\text { findings }\end{array}$ \\
\hline $\begin{array}{l}\text { 4. Evaluation based on subjective } \\
\text { evaluation (workers) }\end{array}$ & a 7,926 workers involving 244 schools & $\begin{array}{l}\text { - Positive client satisfaction findings revealed by quantitative } \\
\text { and qualitative findings }\end{array}$ \\
\hline $\begin{array}{l}\text { 5. Secondary data analyses based } \\
\text { on reports }\end{array}$ & $\begin{array}{l}\text { - } 1,327 \text { reports from } 244 \text { schools involving } \\
223,101 \text { students and } 9,915 \text { workers }\end{array}$ & $\begin{array}{l}\text { - Positive views of the program and workers } \\
\text { - Different stakeholders regarded the program to be } \\
\text { beneficial }\end{array}$ \\
\hline 6. Interim evaluation & $\begin{array}{l}\text { Data collected from } 378 \text { randomly } \\
\text { selected schools from } 2006 \text { to } 2009\end{array}$ & $\begin{array}{l}\text { - Positive evaluation findings } \\
\text { - Improvement measures suggested }\end{array}$ \\
\hline 7. Process evaluation & $\begin{array}{l}\text { - Observation of } 97 \text { teaching units in } 62 \\
\text { schools }\end{array}$ & $\begin{array}{l}\text { High program adherence (around } 85 \% \text { ) } \\
\text { - High ratings on quality of program implementation process }\end{array}$ \\
\hline 8. Focus groups (students) & $\begin{array}{l}252 \text { randomly selected students in } 29 \\
\text { focus groups }\end{array}$ & $\begin{array}{l}\text { - Predominately positive narratives on the program and its } \\
\text { benefits }\end{array}$ \\
\hline $\begin{array}{l}\text { 9. Focus groups based on } \\
\text { implementers }\end{array}$ & $\begin{array}{l}176 \text { randomly selected workers in } 36 \\
\text { focus groups }\end{array}$ & $\begin{array}{l}\text { - Positive evaluation findings } \\
\text { - Improvements made }\end{array}$ \\
\hline 10. Student diaries & a 1,138 randomly selected diaries & - Program, workers and benefits viewed positively \\
\hline 11. Case study & $\begin{array}{l}\text { - } 7 \text { cases at the beginning, with additional } \\
\text { cases collected }\end{array}$ & $\begin{array}{l}\text { - } 5 \mathrm{P} \text { (program, people, process, policy and place) are } \\
\text { important }\end{array}$ \\
\hline 12. Repert & - 104 randomly selected students & $\begin{array}{l}\text { - Self-identity system changed positively after attending the } \\
\text { program }\end{array}$ \\
\hline
\end{tabular}

Table 2: Evaluation findings of the Extension Phase and Community-Based Implementation Phase of Project P.A.T.H.S. in Hong Kong and Tin Ka Ping P.A.T.H.S. Project in China.

\begin{tabular}{|c|c|c|}
\hline Evaluation Strategy & Participants & Major Findings \\
\hline \multicolumn{3}{|l|}{ Extension Phase (2009-2012) } \\
\hline 1. Client satisfaction evaluation (students) & - 242,705 students & - Different aspects evaluated positively \\
\hline 2. Client satisfaction evaluation (workers) & - 9,765 workers & - Positive evaluation of different aspects of the program \\
\hline \multicolumn{3}{|l|}{ Community-Based Phase (2013-2015) } \\
\hline $\begin{array}{l}\text { 1. Subjective outcome evaluation } \\
\text { (students) }\end{array}$ & - 52,263 students & - Positive views of program, workers, and benefits revealed \\
\hline $\begin{array}{l}\text { 2. Subjective outcome evaluation } \\
\text { (workers) }\end{array}$ & - 1,808 workers & - Positive views of program, workers, and benefits revealed \\
\hline $\begin{array}{l}\text { 1. Objective outcome evaluation } \\
\text { (pre-experimental design) }\end{array}$ & - 32,314 students & $\begin{array}{l}\text { - Compared with pretest scores, students showed improvement in different } \\
\text { outcomes, including PYD measures, life satisfaction and thriving }\end{array}$ \\
\hline \multicolumn{3}{|l|}{ Tin Ka Ping P.A.T.H.S. Project (2011-2018) } \\
\hline $\begin{array}{l}\text { 1. Subjective outcome evaluation } \\
\text { (students) }\end{array}$ & - 20,181 students & - Overwhelming positive evaluation of different aspects of the program \\
\hline $\begin{array}{l}\text { 2. Subjective outcome evaluation } \\
\text { (workers) }\end{array}$ & - 442 workers & - Workers had very positive perceptions \\
\hline 3. Qualitative evaluation (diaries) & a 2,938 students & - Content and related themes are positive; positive impact observed \\
\hline
\end{tabular}

the project was implemented again from 2009 to 2012 in the Extension Phase [10-11]. Subjective outcome evaluation findings were positive (Table 2). To enlarge the impact of the project in the community, the community-based phase was launched with a grant of more than HK\$20 million (Table 2). Subjective outcome evaluation findings revealed positive findings
[12]. Evaluation based on pretest and posttest data also showed that the participants showed positive changes on different indicators after joining the program [13].

Tin Ka Ping P.A.T.H.S Project (2011-2018)

As the Hong Kong experience was very successful, 
the Project P.A.T.H.S. was transplanted to China in 2011 with support from Tin Ka Ping Foundation. Based on the pioneer work done in four schools in East China from 2011 to 2014 [14], the project focused on training in 2014/15 school year. From 2015/16 to $2017 / 18$ school year, the project was implemented in more than 30 schools in China [15]. Client satisfaction and qualitative evaluation findings are very positive (Table 2).

\section{Conclusion}

There is evidence suggesting that the Project P.A.T.H.S. in Hong Kong and Tin Ka Ping
P.A.T.H.S. Project in China can promote holistic youth development and prevent adolescent risk behaviour. Additional evaluation data should be further accumulated, particularly those based on randomized group trials.

\section{Acknowledgements}

The Project P.A.T.H.S. and the preparation of this paper were financially sponsored by The Hong Kong Jockey Club Charities Trust. The Tin Ka Ping P.A.T.H.S. Project in mainland China is financially supported by Tin Ka Ping Foundation.

\section{References}

1. Shek DTL, Sun RCF. Development and evaluation of Positive Adolescent Training through Holistic Social Programs (P.A.T.H.S.), Singapore, Springer (2013).

2. Shek DTL, Sun RCF. The Project P.A.T.H.S. in Hong Kong: Development, training, implementation, and evaluation. J. Pediatr. Adolesc. Gynecol 26(3S), 2-9 (2013).

3. Shek DTL, Wu FKY. The Project P.A.T.H.S. in Hong Kong: Work done and lessons learned in a decade. J. Pediatr. Adolesc. Gynecol 29(1), 3-11 (2016).

4. Catalano RF, Berglund ML, Ryan JAM, et al. Positive youth development in the United States: Research findings on evaluations of positive youth development programs. Ann. Am. Acad. Pol. Soc. Sci 591(1), 98-124 (2004).

5. Catalano RF, Fagan AA, Gavin LE, et al. Worldwide application of prevention science in adolescent health. Lancet 379(9826), 1664 (2012).
6. Shek DTL, Ma CMS. Impact of the Project P.A.T.H.S. in the junior secondary school years: objective outcome evaluation based on eight waves of longitudindal data. Scient. World. J 2012(1), 170345 (2012).

7. Shek DTL, Yu L. Longitudinal impact of the Project P.A.T.H.S. on adolescent risk behavior: what happened after five years? Scient. World. J 2012(1), 316029 (2012).

8. Shek DTL. Prevention of drug abuse in Chinese adolescents in Hong Kong: the role of positive youth development. In: Cambridge Handbook of International Prevention Science. Cambridge University Press, Cambridge (2017).

9. Shek DTL. The use of focus groups in programme evaluation: Experience based on the Project P.A.T.H.S. in a Chinese context. In: A New Era in Focus Group Research, Palgrave McMillan, London (2017).

10. Shek DTL, Law MYM. Evaluation of the Project P.A.T.H.S. based on the client satisfaction approach: View of the students. J. Pediatr. Adolesc. Gynecol 27(S), 2-9 (2014).
11. Sun RCF, Shek DTL. Perceived program qualities and outcomes of a youth program in Hong Kong based on the views of the workers. J. Pediatr. Adolesc. Gynecol 27(S), 10-16 (2014).

12. Shek DTL, Leung JTY, Law MYM, et al. (2016). Perceived effectiveness and satisfaction of a community-based positive youth development program: Findings based on high school students. Int. J. Disa. Human. Devel 16(4), 367-375 (2017).

13. Ma CMS, Shek DTL. Objective outcome evaluation of a positive youth development program: The Project P.A.T.H.S. in Hong Kong. Res. Social. Work. Prac 29(1), 4960(2019).

14. Shek DTL, Yu L, Sun RCF, et al. Objective outcome evaluation of a positive youth development program in China. Int. J. Disab. Human. Deve 13(2), 255-265 (2014).

15. Shek DTL, Zhu X, Leung JTY, et al. Evaluation of the Project P.A.T.H.S. in mainland China: Findings based on student diaries. Res. Social. Work. Prac, 1-10 (2017). 